\title{
Gender Differences in Denial-Acceptance Duration Based on Kübler-Ross Cycle After HIV Diagnosis
}

\section{Perbedaan Durasi Penerimaan-Penolakan Siklus Kübler-Ross Setelah Diagnosa HIV Berdasarkan Gender}

\author{
Niniek Budiarti B, M Reza Febriliant \\ Department of Internal Medicine Faculty of Medicine Universitas Brawijaya Malang
}

\begin{abstract}
Patients who have been diagnosed with HIV often suffer from sadness and grief that, in turn, affect the adherence to HIV treatment. This study aimed to examine gender differences in the denial-acceptance duration based on the Kübler-Ross cycle in patients after diagnosed with HIV. A cross-sectional survey was conducted on 63 adult HIV patients aged 19-60 years who received routine treatment at the HIV/VCT outpatient department of Saiful Anwar General Hospital Malang. Subjects were interviewed using the Acceptance of Disease and Impairments Questionnaire (ADIQ). Gender differences in denial-acceptance duration after diagnosed with HIV were analyzed using the unpaired T-test. Results were statistically significant if $p$ value $<0.05$. The median duration of denial-acceptance in male subjects was 16 weeks with the shortest duration of 1 week and the longest duration of 144 weeks, while the median duration of female subjects was 12 weeks with the shortest duration of 1 week and the longest duration of 240 weeks. There are no gender differences in the denialacceptance duration ( $p$ value $=0.629$ ). In conclusion, there are no gender differences in denial-acceptance duration based on the Kübler-Ross cycle after diagnosed with HIV.
\end{abstract}

Keywords: Acceptance, denial, grief, HIV, Kübler-Ross cycle

\begin{abstract}
ABSTRAK
Penderita yang sudah terdiagnosis HIV sering kali mengalami kesedihan dan duka yang mendalam yang berakibat pada kepatuhan terhadap pengobatan HIV. Tujuan penelitian ini adalah untuk mengetahui perbedaan gender dalam durasi penolakan penerimaan siklus Kübler-Ross pada pasien setelah didiagnosis HIV. Survei dilakukan secara cross sectional terhadap 63 pasien HIV dewasa (usia: 19-60 tahun) yang menjalani pengobatan rutin di bagian rawat jalan HIV/VCT RS Saiful Anwar. Subjek diwawancarai dengan Acceptance of Disease and Impairments Questionnaire (ADIQ). Perbedaan jenis kelamin dalam durasi penolakan penerimaan setelah didiagnosis HIV dianalisis menggunakan uji-T tidak berpasangan. Hasil signifikan secara statistik jika $p<0,05$. Durasi rata-rata penolakan penerimaan subjek laki-laki adalah 16 minggu dengan durasi terpendek 1 minggu dan terlama 144 minggu sedangkan subjek perempuan 12 minggu dengan durasi terpendek 1 minggu dan terlama 240 minggu. Tidak ada perbedaan gender dalam durasi penolakan-penerimaan $(p=0,629)$. Kami menyimpulkan bahwa tidak ada perbedaan dalam durasi penolakan penerimaan siklus Kübler-Ross setelah didiagnosis HIV berdasarkan jenis kelamin.
\end{abstract}

Kata Kunci: HIV, duka, siklus Kübler-Ross, penerimaan, penolakan

Correspondence: Niniek Budiarti B. Department of Internal Medicine Faculty of Medicine Universitas Brawijaya Malang, JL. Veteran Malang Tel.08113655665Email:niniek.burhan123@gmail.com

DOI: http://dx.doi.org/10.21776/ub.jkb.2021.031.03.7 


\section{INTRODUCTION}

In the middle of 1981, AIDS (Acquired Immunodeficiency Syndrome) outbreak occurred, in which within a short time there were many patients from gay men in the USA who suffered from Pneumocystis carinii pneumonia. However, in Africa, AIDS appeared to have spread decades earlier. AIDS is caused by the Human Immunodeficiency Virus (HIV), which is a lentivirus spread through sexual contact, blood transfusion, maternal-fetal attachment, and blood-derived products. This virus was probably originated in Central Africa and then spread to Haiti and the United States, and followed by global spread to almost all countries in the world including Indonesia (1). Cambodia, Myanmar, and Thailand are the worst affected countries in Asia with national prevalence rates above 1 percent (2).

AIDS cases in Indonesia, from April to June 2019, were reported as many as 1,463 people with the largest age group of $30-39$ years (34.7\%). AIDS cases reported in the first quarter of 2019 were decreasing from 1,536 to 1,463 people. This decrease was due to the death of AIDS patients. Cumulatively, the number of people living with AIDS from 2005 to 2019 was relatively stable each year. The cumulative number from 1987 to June 2019 was 117,064 people. However, the AIDS mortality rate decreased from $1.03 \%$ in 2018 to $0.3 \%$ in June 2019 (3).

A study conducted at the voluntary counselling and testing (VCT) clinic at Pare General Hospital, Kediri, by interviewing five respondents diagnosed with HIV found that four patients experienced stress. One patient who did not experience stress said that he received good support and attention from his family. Patients who have AIDS show psychological disorders in the forms of anxiety and depression indicated by feelings of sadness, hopelessness, pessimism, feelings of failure, dissatisfaction in life, feeling worse than other people, lower evaluation of their bodies, and unhappy (4).

Based on the Kubler-Ross theory of grief, emotional reactions will arise if there is a loss. The 5 stages that the patient will go through at different times are: 1. Denial, 2. Anger, 3. Bargaining, 4. Depression, 5. Acceptance (5). Initially, obtaining HIV positive diagnosis can affect the very core of the individual as the essence of self is targeted and in need of reform (6). The patient will go through a denial phase of the HIV diagnosis so that the patient feels like a normal person. During this phase, the patient feel does not need medicine, so the drugs given are usually not consumed. This denial phase will be followed by several phases until reaching the acceptance phase of the new condition. There are four key attributes of illness acceptance in adolescents as described in a conceptual model, which are (a) understanding of illness; (b) overcoming limitations; (c) normalization; and (d) readiness for responsibility (7). Adherence to therapy will continue to increase along with the achievement towards the acceptance stage, which is the highest phase of adherence to therapy (8).

Women appear to have a more difficult time accepting an HIV diagnosis and so adherence to therapy also decreases. Women's experiences with HIV-related depression, stress, and stigmatization and a greater focus on social relationships likely affects their levels of adherence. Gender is an important component of one's identity, influencing one's concept of HIV and means by which it is managed. A gendered perspective of adherence can help shape more appropriate and targeted support for individuals accessing ART (9).

The study aimed to examine gender differences in the duration of denial-acceptance based on the Kübler-Ross cycle in patients diagnosed with HIV.

\section{METHOD}

A cross-sectional survey with non-probability sampling (consecutive sampling) was conducted on adult HIV patients aged 19-60 years who received routine treatment at HIV/VCT outpatient department of Saiful Anwar General Hospital Malang. Subjects were selected based on inclusion criteria: 1 . Patients are HIV sufferers who are willing to be the subject of a study volunteered and willing to follow the research until it was completed and signed a form of willingness to be a respondent, 2 . The patient is HIV sufferer and has been routinely controlled at the Tropical and Infection Clinic Medical, 3. Patients are HIV sufferers who have been able to pass the acceptance phase (acceptance) of the conditions experienced. Subjects were interviewed using the Acceptance of Disease and Impairments Questionnaire (ADIQ) to identify their denial and acceptance phase after being diagnosed with HIV. Interviews were conducted on 27 men and 36 women ranging from 19 to 60 years old at the HIV/VCT outpatient department of Saiful Anwar General Hospital Malang. The subjects had agreed to be included in the study. The time duration between the denial phase and the acceptance phase was also recorded. Gender differences in the duration of denial-acceptance after diagnosed with HIV were analyzed using unpaired T-test. Results were statistically significant if $\mathrm{p}<0.05$.

Full ethics approval (No: 400/142/K.3/302/2020) was granted by the Ethics Committee of Saiful Anwar General Hospital Malang before study commencement.

\section{RESULTS}

Subjects consisted of 27 men and 36 women ranging from 19 to 60 years old at the HIV/VCT outpatient department of Saiful Anwar General Hospital Malang. The subjects had reached the acceptance phase, were able to communicate, and were willing to take part in the research.

Table 1. Demographic and clinical characteristics

\begin{tabular}{lr}
\hline & $\mathbf{n}(\%)$ \\
\hline Age & $3(4.7)$ \\
$19-24$ & $51(80.9)$ \\
$25-49$ & $9(14.3)$ \\
$>50$ & \\
Gender & $27(42.9)$ \\
Men & $36(57.2)$ \\
Women & 12 \\
Denial-Acceptance Duration (weeks) & 1 \\
Median & 240 \\
Minimum & \\
Maximum & \\
\end{tabular}

The distribution of denial-acceptance duration was homogenous in both gender $(P<0.05)$. Statistical analysis using the Mann-Whitney test was carried out to determine the differences in denial-acceptance duration in the male 
and female groups. The median duration of denialacceptance after being diagnosed with HIV in men was 16 weeks; the shortest duration was 1 week, and the longest was 144 weeks. Meanwhile, for women, the median duration of denial-acceptance after HIV diagnosis was 12 weeks; the shortest duration was 1 week, and the longest was 240 weeks. There are no statistically significant differences in denial-acceptance duration after HIV diagnosis by gender $(p=0.629)$ (Table 2$)$.

Table 2. Demographic and clinical characteristics

\begin{tabular}{lrc}
\hline & $\begin{array}{c}\text { Median } \\
\text { (Min - Max) }\end{array}$ & p value \\
\hline Men & $16(1-144)$ & 0.629 \\
Women & $12(1-240)$ & \\
\hline
\end{tabular}

\section{DISCUSSION}

At the time when the interview was conducted, the youngest male subject was 19 years old, and the oldest was 53 years, whereas the youngest female subject was 24 years old, and the oldest was 60 years. It can be explained that epidemiologically, HIV patients are in all age ranges, and those in the productive age have the greatest risk. This condition is in line with the report on the Development of HIV AIDS and Sexually Transmitted Diseases for the second quarter of 2019 that the highest percentage of HIV infection was $85.5 \%$ in the $20-49$ age range and only $9 \%$ in $>50$ years old (3).

Statistically, there were no differences in denialacceptance duration for men and women although the median duration for female's denial-acceptance was slightly shorter than that for male's denial-acceptance. However, it is also found that the longest denialacceptance duration among female subjects is up to 240 weeks or 5 years. Meanwhile, there was a male subject who had the longest denial-acceptance duration that is up to 144 weeks or 3 years.

In chronic infectious illness such as Hepatitis B, a study conducted by Febriliant to determine the denialacceptance duration based on the Kübler-Ross cycle in Hepatitis B patients found that the denial-acceptance duration was 20 weeks, longer than that of HIV patients (10).

A study conducted by Li et al. found that HIV-positive women reported a significantly higher level of depressive symptoms than their partners/spouses; thus, family interventions should be gender- and couple-type specific, and mental health counseling is required (11). Renesto et al. found that women suffer and fear not only insecurity of

\section{REFERENCES}

1. Pendse R, Gupta S, Yu D, and Sarkar S. HIV/AIDS in the South-East Asia Region: Progress and Challenges. Journal of Virus Eradication. 2016; 2(4): 1-6.

2. Phanuphak N, Lo YR, Shao Y, et al. HIV Epidemic In Asia: Implications for HIV Vaccine and Other Prevention Trials. AIDS Research and Human Retroviruses. 2015; 31(11): 1060-1076.

3. Pusat Data dan Informasi Kementerian Kesehatan having an incurable disease, but also fear of abandonment and rejection. This circumstance leads to the need to conceal the diagnosis to preserve their personal identity and to maintain family or social relationships. However, those women suffered from institutional stigma due to lack of space to voice the difficulties beyond the disease. Stigmatization is an obstacle in situations that are unable to respond to the complex health needs of these women (12). The women respondent in this study also had the same situation. They tend to shut themselves off from their families and don't tell their families that they have been diagnosed with HIV.

Interventions can be made to shorten the denialacceptance duration. A number of subjects mentioned that they returned to their religious beliefs after being diagnosed with HIV and believe that they had the destiny to live with HIV. Through this way, the acceptance phase can be reached faster. Supervision of the therapy given must also be carried out more closely during this period to reach the acceptance phase. Collaboration is needed among patients, doctors, and patient families to monitor patient adherence to the therapy (13-15).

There are several limitations in this study. Consequently, caution must be taken when interpreting these findings. Due to the cross-sectional nature of this study, it was not possible to discover whether the subjects clearly remembered the duration of denial-acceptance because they had already been in the denial-acceptance phase.

The findings of this study deliver several clinical implications. In patients newly diagnosed with HIV, doctors must provide more empathy and provide knowledge about HIV so that the patient can reach a state of acceptance more quickly. This study is expected to provide knowledge regarding the duration of denial-acceptance based on the Kübler-Ross cycle experienced by male and female HIV patients as well as the differences of duration after obtaining diagnosis result. Therefore, interventions to shorten the duration can be made for patients to escape the negative feelings and to increase the adherence to the therapy program given by doctors.

There was no significant difference in the duration of denial-acceptance between male and female HIV patients. The findings of this study deliver several clinical implications. This study is expected to provide knowledge regarding the duration of denial-acceptance based on the Kübler-Ross cycle experienced by male and female HIV patients as well as the differences of duration after obtaining diagnosis result. Therefore, interventions to shorten the duration can be made for patients to escape the negative feelings and to increase the adherence to the therapy program given by doctors.
Republik Indonesia. Infodatin Situasi Penyakit HIV AIDS di Indonesia. Jakarta: Kemkes RI; 2020: p. 1-12.

4. Widayati D, Hayati F, and Chotijah N. Family Acceptance dan Tingkat Stres Pasien HIV. Jurnal Keperawatan Respati Yogyakarta. 2018; 5(2): 364-369.

5. Kübler-Ross E. On Death and Dying. 1st edition. London: Routledge; 1973.

6. Stroumpouki T, Perret S, KAsdovasili S, Papatheodorou P, Paparizos V, and Stavropoulou A. 
"A Journey towards Acceptance": The Process of Adapting to Life with HIV in Greece. A Qualitative Study. Applied Nursing Research. 2020; 53: 151249151249.

7. Puskas CM, Forrest JI, Parashar S, et al. Women and Vulnerability to HAART Non-Adherence: A Literature Review of Treatment Adherence by Gender from 2000 to 2011. Current HIV/AIDS Reports. 2011; 8(4): 277-287.

8. Zheng $\mathrm{K}$, Bruzzese JM, and Smaldone A. Illness Acceptance in Adolescents: A Concept Analysis. Nursing Forum. 2019; 54(4): 545-552.

9. Brion JM, Menke EM, and Kimbal C. Grief and HIV Medication Adherence: The Work of Transcending Loss. Journal of Loss and Trauma. 2013; 18(6): 499520.

10. Febriliant MR and Pratomo B. Durasi DenialAcceptance Siklus Kübler-Ross pada Pasien Hepatitis $B$. [Mini Research]. Universitas Brawijaya, Malang. 2020.

11. Li L, Liang LJ, Lin C, Ji G, and Xiao Y. Gender Differences in Depressive Symptoms among HIV-
Positive Concordant and Discordant Heterosexual Couples in China. Psychology of Women Quarterly. 2017; 41(1): 89-99.

12. Renesto HMF, Falbo AR, Souza E, and Vasconcelos MG. Coping and Perception of Women with HIV Infection. Revista de Saude Publica. 2014; 48(1): 3642.

13. Gonzalez JS, Batchelder AW, Psaros C, and Safresn SA. Depression and HIV/AIDS Treatment Nonadherence: A Review and Meta-Analysis. Journal of Acquired Immune Deficiency Syndromes. 2011; 58(2): 1-13.

14. Kalichman S, Kalichman MO, and Cherry C. Medication Beliefs and Structural Barriers to Treatment Adherence among People Living with HIV Infection. Psychology \& Health. 2016; 31(4): 383395.

15. Kelly JD, Hartman C, Graham J, Kallen MA, and Giordano TP. Social Support as a Predictor of Early Diagnosis, Linkage, Retention, and Adherence to HIV Care: Results from the Steps Study. The Journal of the Association of Nurses in AIDS Care: JANAC. 2014; 25(5): 405-413. 